\title{
PENGEMBANGAN BAHAN AJAR FISIKA SMA BERBASIS INVESTIGASI PADA MATERI FLUIDA DINAMIS UNTUK MENINGKATKAN HASIL BELAJAR SISWA
}

\author{
Rizki Maulida dan Mariati Purnama Simanjuntak \\ Prodi Pendidikan Fisikan Pascasarjana Universitas Negeri Medan \\ maulida_qq@yahoo.com
}

\begin{abstract}
Abstrak. Penelitian ini bertujuan untuk menganalisis apakah bahan ajar yang dikembangkan dapat meningkatkan respon, aktivitas dan hasil belajar siswa dengan menggunakan pengembangan bahan ajar SMA berbasis investigasi pada materi fluida dinamis berbasis investigasi. Metode yang dilakukan dalam penelitian ini menggunakan penelitian pengembangan Research and Development (R\&D). Sampel penelitian ini adalah satu kelas yaitu kelas XI IPA2. Instrumen yang digunakan untuk mengumulkan data ada tiga yaitu dengan menggunakan lembar validasi bahan ajar berupa angket dan kemudian di validkan oleh tim ahli, untuk menilai respon siswa pada bahan ajar instrumen yang digunakan berupa angket yang dibagikan pada setiap pertemuan dan untuk melihat aktivitas siswa menggunakan angket yang dinilai oleh teman sejawat peneliti dalam mengukur aktivitas siswa pada setiap pertemuan serta untuk melihat hasil belajar siswa digunakan penilaian evaluasi berupa 10 pertanyaan dalam bentuk pilihan berganda yang diberikan pada setiap akhir pertemuan. Hasil penelitian diperoleh: Bahan ajar fisika SMA berbasis investigasi yang dikembangkan dapat meningkatakan respon, aktivitas dan hasil belajar siswa pada pertemuan I, II, III yaitu: respon rata-rata pada pertemuan pertama sebesar 76,42. pada pertemuan kedua sebesar 79,77 dan pada pertemuan ketiga 87,36. Aktivitas rata-rata pada pertemuan pertama sebesar 67,01. pada pertemuan kedua sebesar 71,00 dan pada pertemuan ketiga 79,00. Hasil belajar rata-rata pada pertemuan pertama sebesar 40,36. pada pertemuan kedua sebesar 60,71 dan pada pertemuan ketiga 81,07.
\end{abstract}

Kata kunci: hahan ajar, investigasi, hasil belajar

\section{DEVELOPMENT OF TEACHING MATERIALS PHYSICS BASED INVESTIGATION ON SMA FLUID DYNAMIC MATERIALS TO IMPROVE STUDENT LEARNING OUTCOMES}

\author{
Rizki Maulida dan Mariati Purnama Simanjuntak \\ Physics Education Program, Graduate State University of Medan \\ maulida_qq@yahoo.com
}

\begin{abstract}
The purpose of this study was to analyze whether the teaching materials developed can improve responsiveness, activities, and student learning outcomeusing SMA development of teaching materials based on the material fluid dynamic investigation. The research method was Research and Development (R\&D) research. The research sample was randomly
\end{abstract}


selected by gamble the existing seven classes. The used instrument were three namely using the validation sheet of teaching materials in questioner type and then validated by the expert team, to assess the students' response in teaching materials so the used instrument was questioner given in each meeting and to find out the students' activity used questioner assessed by researcher peer in measuring the students' activity in each meeting and also to find out the students' learning outcomes used evaluation assessment in ten multiple choice problems given in the end of each meeting. Based on the research result obtained: The physics teaching materials of senior high school based on investigation which was developed can improve the response, activity, and learning outcomes of students in meeting I, II, III. The mean response in meeting I was $76.42,79.77$ in meeting II, and 87.36 in meeting III. The mean activity in meeting I was $67.01,71.00$ in meeting II, and 79.00 in meeting III. The mean of learning outcomes in meeting I was 40.36, 60.71 in meeting II, and 81.07 in meeting III.

Keywords: material teaching, investigation, learning outcomes

\section{PENDAHULUAN}

Tuntutan pada saat ini terhadap kualitas manusia yang sangat besar, menjadi salah satu tanggung jawab bagi para pendidik. Guru merupakan tenaga pendidik yang ikut bertanggung jawab atas ketercapaian terhadap kualitas manusia yang akan bersaing dimasa depan untuk mewujudkan kehidupan yang lebih baik (Sani, 2014). Metode saintifik pada umumnya melibatkan kegiatan pengamatan atau observasi yang dibutuhkan untuk perumusan hipotesis atau pengumpulan data. Metode saintifik ini yang membutuhkan kegiatan observasi dan pengamatan sebagai bahan untuk pengumpulan data merupakan metode yang mendukung dalam proses pembelajaran fisika.

Bahan ajar adalah seperangkat materi yang disusun secara sistematis tertulis baik maupun tidak sehingga tercipta lingkungan suasana yang memungkinkan siswa untuk belajar (Daryanto, 2014). Dalam pembelajaran di kelas seorang guru juga sebaiknya memiliki bahan ajar yang tepat. Bahan ajar juga menjadi salah satu faktor pendukung terwujudnya pembelajaran yang efisien. Bahan ajar yang sinergis dan berjalan sesuai dengan model pembelajaran yang akan dilakukan diharapkan mampu meningkatkan hasil belajar. Menurut
Majid (2009) sumber belajar yang diorganisir melalui suatu rancangan yang dimafaatkan sebagai sumber ajar dapat bermanfaat bagi seorang guru mapun peserta didiknya.Bahan ajar yang sesuai dengan model pembelajaran menjadi hal penting agar pembelajaran dapat bermanfaat dan mencapai tujuannya. Menurut (Wena, 2009) pembelajaran kooperatif adalah pembelajaran kelompok yang memiliki aturan tertentu dan prinsip dasar pada pembelajaran kooperatif ini adalah pembentukan kelompok kecil yang saling mengajar untuk mencapai tujuan bersama.

Penggunaan buku sebagai bahan ajar yang saat ini masih menjadi pegangan seorang guru dalam mengajar masih kurang sesuai dengan metode saintifik. Buku yang biasa digunakan oleh guru adalah buku dari penerbit yang mana isi dalam buku tersebut berupa materi dan penugasan dalam bentuk soal.buku yang digunakan guru dari penerbit masih belum selaras dengan model pembelajaran yang saintifik.

Menurut wawancara yang dilakukan oleh siswa juga masih banyak yang memandang fisika adalah pembelajaran hitung yang rumit, sehingga berakibat pada persepsi siswa yang menganggap fisika adalah pembelajaran yang 
sulit. Hal ini juga menjadi akibat dari penyajian pelajaran fisikan yang masih berpusat pada guru. Pelaksanaan pembelajaran yang terjadi disekolah yaitu guru dalam menyampaikan materi pada saat ini masih lebih dominan menggunakan model pembelajaran langsung, dan berupa penyampaian materi dengan diakhiri penugasan-penugasan. Penggunaan bahan ajar dalam proses pembelajaran juga masih berpusat pada buku paket. Proses pembelajaran yang berpusat pada guru ini juga terjadi di sekolah MAN 1 Medan bahan ajar yang digunakan oleh guru sebagai pegangan menggunakan buku dari penerbit Platinum, dan dalam penerapannya dalam proses pembelajaran masih berupa menjelaskan materi dan membahas soal sebagai penugasan.

Bahan ajar yang masih kurang sesuai dengan model pembelajaran yang digunakan ini juga menjadi faktor penentu proses pembelajaran yang terjadi didalam kelas. didalam kelas Penggunaan bahan ajar yang masih berpusat pada guru ini membuat aktivitas siswa berkurang. Aktivitas siswa yang rendah juga mengakibatkan kejenuhan siswa dan rendahnya semangat dalam belajar fisika yang mengakibatkan rendahnya hasil belajar kognitif siswa. Penggunaan bahan ajar yang menuntut siswa dalam memecahkan masalah melalui konsep, matematis dan prinsip fisika akan membuat siswa lebih aktif dan menuntut siswa untuk lebih mengaplikasikan pengetahuannya. Penggunaan bahan ajar dan model pembelajaran yang masih berpusat pada guru ini juga menjadi penyebab rendahnya minat belajr fisika pada siswa, minimnya minat belajar mengakibatkan transfer ilmu menjadi sulit diterima siswa hasil belajar siswa yang rendah menjadi gambaran mengenai kurang maksimal seorang siswa menerima pelajaran.Pada materi tertentu antara lain materi fluida dinamis pada umumnya hasil belajar siswa rendah, sedangkan pada materi tersebut seharusnya banyak hal yang dapat kita kembangkan berdasarkan kehidupan seharihari. Kebutuhan akan penggunaan bahan ajar yang sesuai dengan motode saintifik menjadi perhatian penting tersendiri.
Pengembangan bahan ajar berbasis investigasi ini bertujuan untuk menganalisis peningkatkan respon siswa dan aktivitas belajar siswa serta hasil belajar siswa setelah menggunakan pengembangan bahan ajar berbasis investigasi pada materi fluida dinamis. Manfaat dari hasil penelitian ini dapat memberikan sumbangan pemikiran dalam bentuk bahan ajar yang dapat digunakan guru, sehingga siswa dapat mengembangkan aspek kemampuan dasar yang mencakup aspek kognitif siswa dan sebagai bahan informasi bagi peneliti selanjutnya dalam melakukan penelitian lebih lanjut

\section{METODE PENELITIAN}

Penelitian ini akan dilaksanakan pada Semester II Kelas XI di MAN 1 Medan yang beralamat Jalan Willem Iskandar no. 7B. Populasi dalam penelitin ini adalah seluruh siswa kelas XI IPA semester 2 pada Tahun 2015 di MAN 1 Medan. Sampel yang ditetapkan dalam penelitian ini adalah satu kelas XIIPA2 dari semua kelas yang ada di tempat penelitian.

Penelitian ini dirancang sebagai penelitian pengembangan produk menggunakan metode pengembangan Research and Development (R\&D). Metode Research and Development (R\&D) ini digunakan untuk menghasilkan produk tertentu, dan menguji keefektifan model tersebut.

\section{HASIL PENELITIAN DAN PEMBAHASAN}

Penelitian ini bertujuan untuk melihat analisis peningkatan respon belajar siswa dan menganalisis aktivitas belajar siswa serta menganalisis hasil belajar siswa. Deskripsi data hasil penelitian ini terdiri dari skor hasil validitas (SV) tim ahli yaitu berupa materi dan media bahan ajar yang dikembangkan, hasil respon siswa (HR) terhadap pengembangan bahan ajar berbasis investigasi, hasil aktivitas (HA) belajar siswa pada saat pembelajaran dengan menggunakan pengembangan bahan ajar berbasis investigasi, dan skor hasil belajar (HB) siswa dengan menggunakan pegembangan bahan ajar berbasis investigasi. Pada tahap pertama pengembangan bahan ajar berbasis 
investigasi mendapatkan skor hasil validasi oleh tim ahli tertera pada tabel 1.

Tabel 1. Hasil Validasi Materi Oleh Tim Ahli

\begin{tabular}{clc}
\hline No & \multicolumn{1}{c}{ Aspek } & Persentase \\
\hline 1 & Kelayakan Isi & $83,85 \%$ \\
2 & Kelayakan Penyajian & $81,41 \%$ \\
3 & Kontekstual & $80,56 \%$ \\
4 & Kesesuaian dengan & $86,90 \%$ \\
\hline & Investigasi & \\
\hline
\end{tabular}

Hasil validasi bahan ajar oleh bahan ajar terdapat empat aspek anataralain aspek kelayakan dengan jumlah $83,85 \%$ dengan kategori valid, aspek kelayakan penyajian dengan jumlah 81,41 dengan kategori valid, aspek kontekstual dengan jumlah 80,56 dengan kategori valid dan aspek kesesuaian dengan investigasi dengan jumlah $86,90 \%$ dengan kategori sangat valid.

Selain dari validasi pada materi pada bahan ajar juga dilakukan validasi terhadap desain pada bahan ajar. Pada validasi terhadap bahan ajar ini dilakukan oleh tim ahli. Hasil validasi tim ahli terhadap desain bahan ajat tertera pada tabel 2 .

Tabel 2. Hasil Validasi Bahan Ajar Pada

Desain Bahan Ajar Oleh Tim Ahli

\begin{tabular}{clc}
\hline No & \multicolumn{1}{c}{ Aspek } & Persentase \\
\hline 1 & Ukuran Modul & $70,83 \%$ \\
2 & Keakuratan Materi & $79,17 \%$ \\
3 & Desain Isi Modul & $88,67 \%$ \\
\hline
\end{tabular}

Hasil validasi oleh tim ahli terhadap bahan ajar terdiri dari tiga aspek yaitu ukuran modul dengan jumlah $70,83 \%$ dengan kategori cukup valid, keakuratan materi 79,1 dengan kategori valid dan desain isi modul dengan jumlah 88,68 dengan kategori sangat valid.

Terdapat beberapa perbaikan yang dilakukan berdasarkan saran para ahli antara lain: (1) keluasan materi, yaitu menambahkan beberapa aplikasi azas bernoulli pada kehidupan sehari-hari. (2) mengganti rangkaian pipa venturi pada percobaan pipa venturi. (3) memperjelas ganbar dan ilustrasi yang terdapat pada bahan ajar. (4) memperjelas peta konsep. (5) membuat soal dan contoh soal pada setiap submateri. (6) membuat daftar pustaka. (7) memperjelas bahasa, tulisan dan kosa kata yang digunakan pada bahan ajar.

Setelah mendapatkan hasil validasi oleh tim ahli kemudian bahan ajar dilakukan revisi sesuai saran dari tim ahli. Bahan ajar yang sudah dilakukan revisi kemudian dilakukan uji coba terbatas kepada satu kelas yang dipilih pada tempat penelitian. Hasil respon siswa terhadap bahan ajar diperoleh hasil yang tertera pada tabel 3. Adapun aspek penilaian validasi yang dilakukan antara lain:

1. Materi Modul: Keluasan Materi, Contoh aplikasi, Latihan-latihan, Bahan Pratikum, Uji Kompetensi

2. Format Modul: Pengetikan, Kalimat, Bahasa yang digunakan, Tampilan bahan ajar

Tabel 3. Hasil Respon Siswa Terhadap Bahan Ajar

\begin{tabular}{lll}
\hline No & Pertemuan & Persentasi \\
\hline 1 & Pertemuan I & $77,18 \%$ \\
2 & Pertemuan II & $81,16 \%$ \\
3 & Pertemuan III & $88,39 \%$ \\
\hline
\end{tabular}

Hasil respon siswa pada pertemuan I adalah 77,18\%. Pada pertemuan UU 81,16 dan pada pertemuan III $88,39 \%$. Dari hasil respon yang diperoleh pada setiap pertemuan dapat dilihat bahwa terdapat peningkatan respon siswa yang signifikan pada setiap pertemuan. Hasil dari respon siswa tersebut menjadi dasar untuk melakukan revisi bahan ajar yang sudah digunakan. Untuk lebih jelas peningkatan respon siswa dapat dilihat pada gambar 1 .

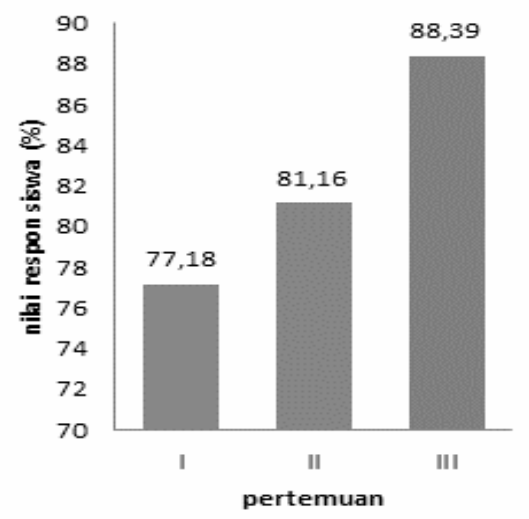

Gambar 1. Persentase Peningkatan Respon Siswa Pada Setiap Pertemuan 
Pada hasil respon siswa terdapat beberapa bagian yang dilakukan perbaikan berdasarkan saran dari siswa, antara lain: (1) mengganti contoh soal agar sesuai seperti peristiwa kehidupan sehari-hari. (2) menambah pertanyaan agar mendorong rasa ingin tahu. (3) menambah kata-kata motivasi pada bahan ajar. (4) memperjelas kalimat yang terdapat pada bahan ajar. (5) merubah tampilan bahan ajar menjadi lebih menarik

Pada penelitian ini selain respon siswa terhadap bahan ajar, juga dilihat aktivitas dan hasil belajar siswa. Secara ringkas hasil aktivitas belajar siswa dengan menggunakan pengembangan bahan ajar berbasis investigasi terlihat pada tabel 4

Tabel 4. Hasil aktivitas siswa dengan menggunakan pengembangan bahan ajar berbasis investigasi

\begin{tabular}{llccc}
\hline No & $\begin{array}{c}\text { Aspek } \\
\text { Penilaian }\end{array}$ & $\begin{array}{c}\text { Pertem } \\
\text { uan I }\end{array}$ & $\begin{array}{c}\text { Pertemu } \\
\text { an II }\end{array}$ & $\begin{array}{c}\text { Pertemu } \\
\text { an III }\end{array}$ \\
\hline 1 & Visual & $77,3 \%$ & $80,9 \%$ & $85,7 \%$ \\
2 & Oral & $76,2 \%$ & $77,3 \%$ & $82,1 \%$ \\
3 & Listening & $76,2 \%$ & $80,9 \%$ & $82,1 \%$ \\
4 & Writing & $78,5 \%$ & $82,1 \%$ & $83,3 \%$ \\
5 & Motor & $78,5 \%$ & $79,7 \%$ & $83,3 \%$ \\
6 & Mental & $64,2 \%$ & $73,8 \%$ & $79,9 \%$ \\
7 & Emotional & $77,3 \%$ & $79,7 \%$ & $80,9 \%$ \\
Rata-rata & $76,19 \%$ & $79,25 \%$ & $85,71 \%$ \\
\hline
\end{tabular}

Rerata hasil aktivitas belajar siswa pada pertemuan I, II dan III terlihat pada gambar 2 .

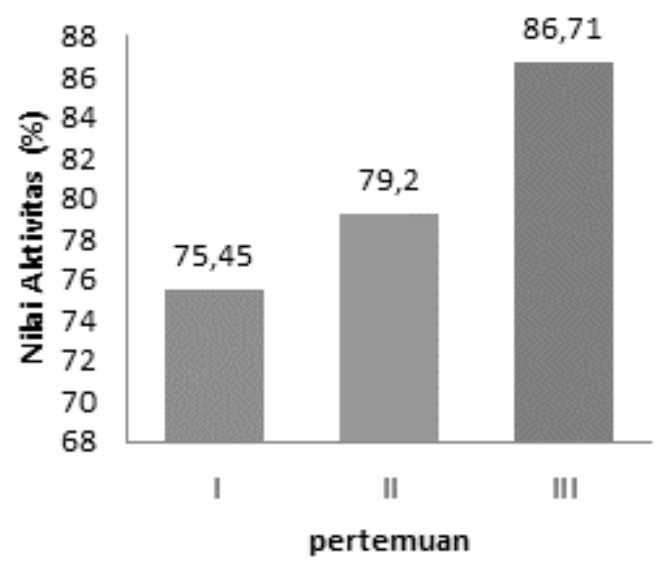

Gambar 2. Persentase nilai aktivitas belajar siswa pada setiap pertemuan
Penilaian hasil belajar dilakukan dengan melakukan evaluasi pada setiap akhir proses pembelajaran. Terdapat tiga hasil evaluasi yang diperoleh pada penelitian ini. Secara ringkas hasil belajar siswa dijelaskan pada tabel 5 .

Tabel 5. Hasil belajar siswa

\begin{tabular}{lll}
\hline No & Pertemuan & Rata-rata \\
\hline 1 & Pertemuan I & 40,36 \\
2 & Pertemuan II & 60,71 \\
3 & Pertemuan III & 81,07 \\
\hline
\end{tabular}

Hasil belajar siswa pada penelitian ini terlihat bahwa pada pertemuan I rerata hasil belajar siswa adalah 40,36. Selanjutkan pada pertemuan II hasil belajar siswa adalah 60,71 serta pada pertemuan III hasil belajar siswa adalah 81,07. Penjelasan pada tabel 5 terlihat jelas bahwa terdapat peningkatan hasil belajar siswa yang signifikan antara hasil belajar siswa pada pertemuan I, II dan III.

Penelitian tentang pengembangan ini juga pernah dilakukan oleh beberapa peneliti sebelumnya yaitu Parmin (2012) hasil dari penelitiannya adalah $72 \%$ siswa menyatakan modul sangat diperlukan dan 68\% mahasiswa yang dijadikan sasaran mendapatkan nilai A dan Budiyasa (2013) hasil penelitiannya adalah bahan ajar online efektif meningkatkan prestasi belajar dalam pembelajaran IPA tingkat SMA kelas delapan semester dua. Astawan (2013) hasil penelitiannya adalah tes hasil belajar siswa sebelum menggunakan modul dan sesudah menggunakan modul dengan menggunakan modul meningkat. Satria (2014) hasil penelitiannya adalah siswa mengalami kenaikan nilai sebesar $32,30 \%$ setelah menggunakan bahan ajar yang telah dikembangkan.

\section{KESIMPULAN}

Berdasarkan hasil analisis data temuan dan pembahasan selama pembelajaran dengan menggunakan pengembangan bahan ajar berbasis investigasi diperoleh beberapa kesimpulan yang berupa jawaban dari pertanyaan-pertanyaan yang diajukan dalam rumusan masalah. Kesimpulankesimpulan tersebut sebagai berikut (1) Pembe- 
lajaran dengan menggunakan pengembangan bahan ajar berbasis investigasi terdapat peningkatakan respon siswa pada pertemuan I, II, III yaitu respon rata-rata pada pertemuan pertama sebesar 76,42, pada pertemuan kedua sebesar 79,77 , dan pada pertemuan ketiga $87,36 \%$. (2) Pembelajaran dengan menggunakan pengembangan bahan ajar berbasis investigasi terdapat peningkatakan aktivitas siswa pada pertemuan I, II, III yaitu aktivitas rata-rata pada pertemuan pertama sebesar $67,01 \%$, pada pertemuan kedua sebesar $71,00 \%$, dan pada pertemuan ketiga $79,00 \%$. (3) Pembelajaran dengan menggunakan pengembangan bahan ajar berbasis investigasi terdapat peningkatakan hasil belajar siswa pada pertemuan I, II, III yaitu aktivitas rata-rata pada pertemuan pertama sebesar 40,36, pada pertemuan kedua sebesar 60,71, dan pada pertemuan ketiga 81,07.

Berdasarkan hasil pembahasan dan simpulan, saran yang dapat dikemukakan adalah (1) Bagi guru yang ingin menerapkan pengembangan bahan ajar berbasis investigasi dalam kegiatan belajar mengajar hendaknya melakukan pembagian kelompok dengan kombinasi kemampuan siswa yang bervariasi untuk membantu mengatasi terbatasnya ketersediaan waktu dalam pembimbingan pada fase-fase praktik. (2) Bagi guru yang ingin menerapkan pengembangan bahan ajar berbasis investigasi sebaiknya melakukan analisis dan kesimpulan lembar kerja siswa dengan menunjuk siswa selain menunggu kesediaan siswa untuk menghindari dominasi oleh siswa tertentu dalam kelompok dan menghilangkan adanya waktu menunggu. (3) Bagi peneliti selanjutnya yang ingin mengembangkan bahan ajar fisika dalam pembeljaran hendaknya menggunakan basis yang berbeda pada pengembangan bahan ajar yang akan dilakukan

\section{DAFTAR PUSTAKA}

Astawan. 2013. Pengembangan Modul Berbasis Model Pembelajaran Kooperatif Tipe Group Investigation Pada Mata Pelajaran Server Jaringan Di Smk Ti Bali Global Sarjana. E-Journal Program Pascasarjana Universitas Pendidikan Ganesha. Vol 3-2013.

Budiyasa, I.M. 2013. Pengembangan bahan ajarassessment alternatif online mata pelajaran IPA tingkat SMP kelas Delapan dengan model Dick and Carey. E-Journal Program Pascasarjana Universitas Pendidikan Ganesha. Vol 3-2013

Daryanto. 2014. Pengembangan perangkat Pembelajaran. Yogyakarta: Gava Media.

Majid, A. 2009. Mengembangkan Standar Kompetensi Guru. Bandung: Remaja Rosdakarya.

Parmin. 2012. Pengembangan Modul Mata Kuliah Strategi Belajar Mengajar IPA Berbasis Hasil Penelitian Pembelajaran. Jurnal Pendidikan IPA Indonesia. Vol 1(2012)8-15.

Satria, B. 2014. Pengembangan bahan ajar berbasis model problem based learning pada pokok bahasan pencemaran lingkungan untuk meningkatkan hasil belajar siswa kelas X SMA Negeri Grunjungan Bondowoso. Universitas Jember.

Sani, R.A. 2014. Pembelajaran Saintifik. Jakarta: PT Bumi Aksara.

Wena, M. 2009. Strategi dan Inovasi Pembelajaran Kontemporer. Jakarta: Bumi Aksara. 